\author{
L.V. Chirkova ${ }^{1}$, K.T. Yermaganbetov ${ }^{1}$, E.B. Skubnevsky², \\ K.M. Mahanov ${ }^{1}$, E.T. Arinova ${ }^{3}$, A. Omirbek ${ }^{1}$ \\ ${ }^{I} Y$ e.A. Buketov Karaganda State University, Kazakhstan; \\ ${ }^{2}$ Institute of Semiconductor Physics of Siberian Branch of Russian Academy of Sciences, Novosibirsk, Russia; \\ ${ }^{3}$ Gymnasium № 1, Karaganda, Kazakhstan \\ (E-mail: ket3853@mail.ru)
}

\title{
Physical processes in Gunn diode and energy balance
}

\begin{abstract}
In article the physical processes happening in Gunn diode which is under the influence of strength electric field exceeding threshold value are analyzed. It is shown that because of transition of electrons from the lower central power area to the top side valley of a power range of arsenide of gallium carriers of a charge are divided into two groups: the «light» and «heavy» electrons having respectively big and smaller drift mobility. At the same time there is an electric domain which resistance is more than resistance of other part of Gunn diode of therefore tension of internal electric field of the diode will exceed electric field strength out of the domain. With growth of tension of external electric field falling of potential on the domain grows, and out of the domain decreases. Growth of drift speed of electrons of the electric domain and reduction of drift speed of electrons out of it is at the same time observed. Formation of the domain comes to the end when drift velocity electrons in the domain and out of it are compared. Steady state in Gunn diode is established when integral Lagrangian reaches the minimum value.
\end{abstract}

Keywords: power range, power valleys, and electron, drift velocity, integral Lagrangian, potential, electric field strength, electric domain, Gunn diode.

It is known that formation of the domain of the strong field in the environment is connected with the fluctuations of a spatial charge resulting in not stability. In the carrying-out substance for which of Ohm's law is fair fluctuation of a spatial charge fades. This attenuation under the exponential law to a constant Maxwell time of a relaxation [1]

$$
\tau_{m}=\varepsilon / 4 \pi \sigma_{0}=\varepsilon / 4 \pi q \mu_{1} n_{0},
$$

where $\varepsilon-$ dielectric constant of medium; $\sigma_{0}-$ conductivity; $q-$ electron charge; $\mu_{1}-$ electron mobility, $n_{0}$ - electron concentration.

Maxwell relaxation time can be explained as follows. The spatial charge resolves under the influence of the related field. According to Coulomb's law this interaction in inverse proportion to dielectric permeability of the environment $\varepsilon$. Therefore $\tau_{m} \approx \varepsilon$. On the other hand, the resolution of a charge occurs quicker, than conductivity of the environment is more $\sigma_{0}$.

In semiconductors, as is well-known [1,2], the fluctuations of a spatial charge causing instability do not resolve. This scientific work is connected with a research of the nature of emergence of fluctuation of a spatial charge which results in not stability on the example of Gunn diode.

In total instability in semiconductors which are in a basis of functioning of the majority of semiconductor devices, are rather well studied [3, 4]. This instability can consider as manifestation of the selforganization arising in thermodynamic nonequilibrium system.

Functioning of the diode of Gunn is connected with not stability caused by fluctuations of a spatial charge in GaAs gallium arsenide — the semiconductor which possesses a specific power range (Fig. 1). 


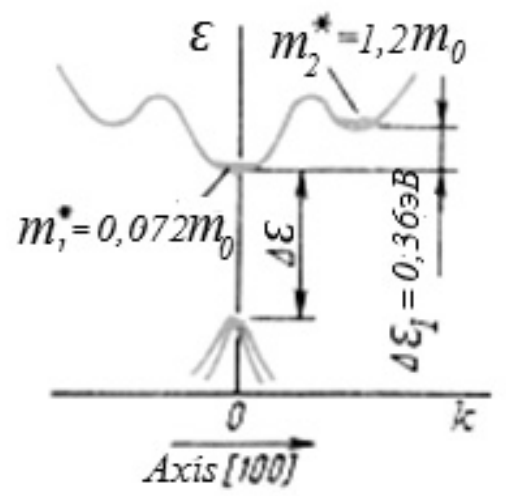

Figure 1. Structure of energy bands of gallium arsenide of GaAs in the crystallographic direction [111]

The power chart GaAs [5,6] constructed in space of quasi pulses in the crystallographic direction [111] has several minima - several power valleys (Fig. 1). The effective mass of electrons in the central outer valley $m_{1}^{*}=0,072 m_{0}$ (here $m_{0}$ - electron mass) much less than the effective mass of electrons in outer valley $m_{2}^{*}=1,2 m_{0}$, т.e $m_{2}^{*}>>m_{1}^{*}$. Therefore in this semiconductor there can be electrons with various mobility $\mu_{1}=\frac{q\langle\tau\rangle}{m_{1}^{*}}$ и $\mu_{2}=\frac{q\langle\tau\rangle}{m_{2}^{*}}-$ «light» и «heavy» electron. The ratio between concentration of «light» и «heavy» electrons changes depending on intensity of external exciting electric field. At the same time full concentration of electrons of conductivity in the semiconductor remains invariable: $n_{0}=n_{1}+n_{2}$. It results in some features of transfer of a charge via the semiconductor which are the cornerstone of the principle of operation of Gunn diode.

Gunn diode represents a sample of gallium arsenide of GaAs or InP indium phosphide of n-type. If to put electric field to a sample $E$, which is more than some threshold value then in a sample $E_{n o p}$ to a sample there is an area of strong electric field (domain) drifting from the cathode to the anode and disappearing at the anode. This process periodically repeats. And when forming the domain current decreases, and at disappearance - again increases.

In Gunn diode near areas of the anode and cathode there are always defects (Fig. 2). Local electric field $E$ strength near defects can exceed threshold tension $E>E_{n o p}$ electric field. Increase in energy of the electrons which appeared in these areas is as a result possible, and they will be able to pass into an overlying side minimum. A part of the energy received by electrons from an external source will be transformed to thermal energy, i.e. there is energy dissipation.

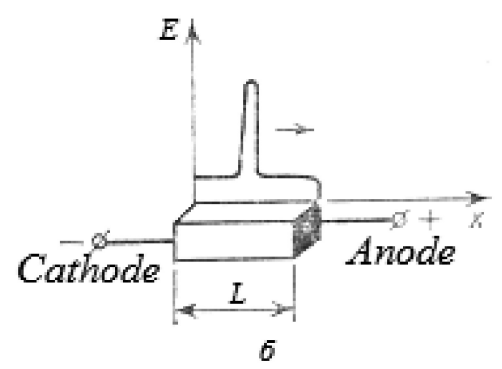

Figure 2. Gunn sample - the uniform semiconductor material GaAs with two ohmic contacts and high-quality distribution of the field along a sample [2]

The electrons which passed into a side overlying minimum of a power range from the category of «light» will pass into the category of «heavy». Thus, reduction of number of «easy» electrons will be fol- 
lowed by increase in number of «heavy» electrons, i.e. the coordinated behavior of subsystems of these two classes of electrons will take place. In the considered system the self-organization process caused by feature of power structure of the semiconductor will proceed. Speed of drift of «light» electrons to the anode is more than the speed of drift of «heavy» electrons. As a result in the neighborhood of defect from the cathode because of a congestion of «heavy» electrons the negatively charged layer is created, and from the anode because of a lack of electrons there is a layer positively charged the donor impurity. The new structure the domain consisting of two layers is created: the negatively charged layer formed from the cathode by surplus of «heavy» electrons, and from the anode - the positively charged layer formed by ions the donor impurity (Fig. 3).

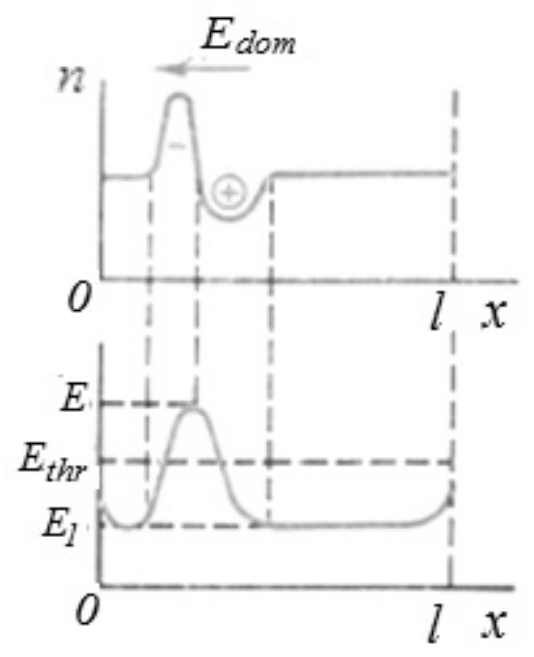

Figure 3. Distribution of concentration of electrons and electric field strength in a crystal after formation of the domain [5]

Thus, during process of self-organization in the considered system there are more complex and more perfect structures.

Resistance of a domain layer determined by the movement of «heavy» electrons exceeds resistance of other part of Gunn diode determined by the movement of «light» electrons.

The direction of electric field of the domain $E_{\text {дом }}$ coincides with the direction of the exciting field attached to the semiconductor. Therefore, with a growth of the external field, in process of formation of the domain the field grows in it, and outside the domain decreases. It leads to increase in drift speed of «heavy» electrons in the domain and to reduction of drift speed of «light» electrons beyond its limits, i.e. the coordinated course of processes in system is again observed. In some time point the drift speed of the movement of «heavy» electrons of $v_{m . \partial p}$, that is speed of the movement of the domain, will appear the equal drift speed of the movement of «light» electrons $v_{\text {л..p }}$ :

$$
\mathrm{v}_{\text {лдр }}=\mathrm{v}_{\text {mдр }} \text {. }
$$

As a result of it process of formation of the electric domain will end, and it will begin to move from the cathode to the anode.

It is obvious that the speed of drift of "easy" electrons will be less than the speed of drift of electrons for

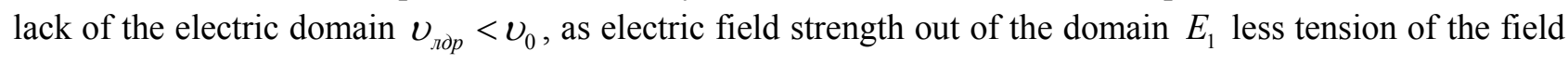
in the absence of the domain $E_{0}: E_{1}<E_{0}$. Therefore after formation of the domain density of current decreases up to the value

$$
J_{\text {min }}=q n_{0} \mathrm{v}_{\text {лдр }} .
$$

The minimum value of density of current through a crystal remains during time of the movement of the domain through a crystal or during time of its flight from the cathode to the anode

$$
t_{\text {прол }}=l / v_{\text {лдр }},
$$

where $l$ - crystal length. 
At achievement of the anode the domain disappears and density of current increases up to value $I_{\max }$, of the domain corresponding to absence. After that at the cathode the new domain is formed, and process repeats (Fig. 4)

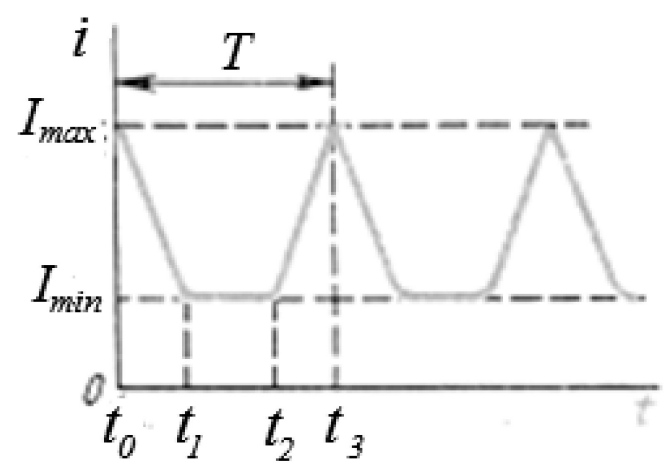

Figure 4. Dependence of the current passing through Gunn diode from time: $\mathrm{t}_{0}$ — time point corresponding to the beginning of formation of the domain; $t_{1}$ - time point corresponding to the end of formation of the domain;

$t_{2}$ - time point corresponding to the beginning of disappearance of the domain on the anode; $t_{2}-$ time point corresponding to total disappearance of the domain on the anode and to origin of the second domain on the cathode [5]

The considered mechanism of operation of the device with intervalley transition of electrons corresponds to a transit time [6, 7]. Electric field in the domain grows in this mode during its formation, and outside the domain decreases. For this reason only one domain as transition of electrons in side can come from the central valley only in the domain where totals electric field strength exceeds threshold value can be formed.

Transit time of the domain from the cathode to the anode has to exceed time of its formation otherwise the domain will not manage to be created. Therefore the condition of emergence of the electric domain in Gunn diode will have an appearance:

$$
t_{\text {прол }}=l / v>\varepsilon_{0} \varepsilon \rho, \text { или } n_{0} l>>\varepsilon_{0} \varepsilon v /\left(q \mu_{2}\right) .
$$

Let's consider balance of energy in Gunn's diode in the presence of the electric domain.

Formation of the electric domain leads to the following changes in structure of Gunn diode and his volts - the ampere characteristic:

- out of the domain there are areas where transfer of a charge is carried out by «light» electrons $n_{1}$, drift with a velocity $v_{л д р}$, and area in the domain where the charge is transferred by the «heavy» electrons drifting with a speed $v_{\text {тдр }}$ which is less, that $v_{\text {лдр }}$, that is $v_{\text {тдр }}<v_{\text {лдр }}$;

- resistance of area of the electric domain will exceed resistance of other part of the semiconductor of the diode of Gunn out of the domain. Therefore power failure on the domain $U_{\text {внуm }}$ will be more, than voltage drop on other part of the diode $U_{\text {вне }}$ out of the domain: $U_{\text {втут }}>U_{\text {вне }}$;

- currents proceeding on the domain $I_{\text {внут }}$ and out of $I_{в н е ~}$ it will be various: $I_{\text {внут }}<I_{в н е}<I_{a}$.

Let's analyzed balance of energy in Gunn's diode in case of formation of the electric domain.

Let tension be attached to the diode $U_{a}$. In case of lack of the electric domain in the diode current will proceed $I_{a}$.

The processes happening in Gunn's diode have several temporary characteristics:

- time of a relaxation of «light» electrons $\tau_{\text {лpen }}=\frac{m_{n} \mu_{l}}{q}$;

- average time of drift $\tau_{л д р}$ of «light» electrons with a speed $v_{\text {лдр }}: \tau_{л д р}=l / v_{л д р}$, in the presence of the electric domain;

- average time of drift $\tau_{a \partial p}=l / v_{a \partial p}$ of «light» electrons with a speed $v_{a \partial p}$, when the electric domain is absent. 
Average speed of drift of electrons of $v_{a}$ on the diode for lack of the domain is more than average

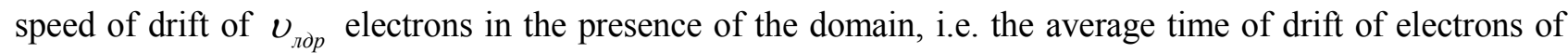
$\tau_{a}$ in lack of the domain is less, than the average time of drift is $\tau_{\text {лдр }}$ in presence of domain.

Between average times of drift of electrons via the diode at absence in it the electric domain $\tau_{a \partial p}$ and in presence of electric domain $\tau_{л д p ~}$ and in presence of electric domain:

$$
\frac{\tau_{a \partial p}}{\tau_{\text {лдр }}}=\frac{v_{\text {лдр }}}{v_{a \partial p}}=\frac{E_{\text {вне }}}{E_{a}}=\frac{U_{\text {вне }}}{U_{a}} .
$$

Power $I_{a} U_{a}$, arriving from an external source to Gunn diode, after formation of the electric domain will be distributed as follows:

- a part of power of $\left(I_{a}-I_{\text {вне }}\right) U_{a}$ will be spent for formation of the domain;

- a part of power of $I_{\text {вне }} U_{\text {вне }}$ will be allocated out of the domain;

- and part of power of $I_{\text {внуm }} U_{\text {внуm }}$ - will be allocated in the domain and it will be spent for overcoming resistance of the environment at the movement of the domain from the cathode to the anode. take place

If to neglect losses on thermal energy, then according to the law of energy conservation equality will

$$
U_{a} I_{a}=I_{\text {внут }} U_{\text {внут }}+I_{\text {вне }} U_{\text {вне }}+\left(I_{a}-I_{\text {вне }}\right) U_{a},
$$

where $U_{d}=U_{a}-U_{\text {вне }}$ - tension on the domain, $I_{a}=e N / \tau_{\text {адр }}$ - current via Gunn diode in absence of electric domain.

Having increased both parts of equality of (7) for the period of $\tau_{\text {лpeл }}$, we will receive balance of energy in the range of time, corresponding to the average time of a relaxation of the $\tau_{\text {лрел }}$ electrons

$$
W_{N}=W_{\text {пер }}+W_{\text {вне }}+W_{\text {рдом }},
$$

where $W_{N}$ - energy transferred by a source to Gunn diode during a relaxation $\tau_{\text {лрел }} ; W_{\text {вне }}$ - energy, received by electrons out of the electric domain; $W_{n e p}$ — energy spent by the domain for overcoming resistance of the environment, that is the energy concluded in the domain; $W_{\text {рдом }}$ - energy, spent for formations of the domain - potential energy of the domain. Let's find expressions for each component of energy in (8).

For lack of the electric domain during the free run of $\tau_{\text {лрел }}$ between collisions the energy equal will be reported to Gunn diode

$$
W_{N}=I_{a} U_{a} \tau_{\text {лрел }}=\left(-q N / \tau_{a}\right) U_{a} \tau_{\text {лpeл }}=-q N U_{a} \frac{\tau_{\text {spen }}}{\tau_{\text {aдp }}} .
$$

The energy received from an external source during a relaxation by $\tau_{\text {лpeл }}$ electrons which are out of the domain will be equal

$$
W_{\text {вне }}=I_{\text {вне }} U_{\text {вне }} \tau_{\text {лрел }} .
$$

Considering ratios of (6) and $I_{\text {вне }}=I_{a} \frac{U_{\text {вне }}}{U_{a}}=I_{a} \frac{E_{\text {вне }}}{E_{a}}, U_{\text {вне }}=U_{a} \cdot \frac{U_{\text {вне }}}{U_{a}}=U_{a} \cdot \frac{E_{\text {вне }}}{E_{a}}$, equality (10) it is possible to lead to the following look

$$
W_{\text {вне }}=I_{\text {вне }} U_{\text {вне }} \tau_{\text {лрел }}=I_{a} U_{a} \tau_{\text {лрел }} \frac{E_{\text {вне }}^{2}}{E_{a}^{2}}=-\frac{q N}{\tau_{a}} U_{a} \frac{E_{\text {вне }}^{2}}{E_{a}^{2}} \tau_{\text {лрел }}=-q N U_{a} \frac{E_{\text {вне }}^{2}}{E_{a}^{2}} \frac{\tau_{\text {ллек }}}{\tau_{\text {адр }}}=W_{N} \frac{E_{\text {вне }}^{2}}{E_{a}^{2}} .
$$

This part of energy during dispersion of electrons on a crystal lattice turns into thermal energy. The energy spent for formation of the domain during a relaxation of $\tau_{\text {лрел }}$, that is the potential energy of electrons in the domain which is saved up in an interval between collisions with phonons can be presented how 


$$
\begin{gathered}
W_{\text {рдом }}=\left(I_{a}-I_{\text {вне }}\right) U_{a} \tau_{\text {лрел }}=I_{a}\left(1-\frac{E_{\text {вне }}}{E_{a}}\right) U_{a} \tau_{\text {лрел }}=-\frac{q N}{\tau_{a}}\left(1-\frac{E_{\text {вне }}}{E_{a}}\right) U_{a} \tau_{\text {лрел }}=-q N U_{a}\left(1-\frac{E_{\text {вне }}}{E_{a}}\right) \frac{\tau_{\text {лрелл }}}{\tau_{a}}= \\
=W_{N}\left(1-\frac{E_{\text {вне }}^{2}}{E_{a}^{2}}\right) .
\end{gathered}
$$

The energy spent by the domain for overcoming resistance of the environment at its movement from the cathode to the anode is equal

$$
W_{\text {пер }}=I_{\text {вне }} U_{d} \tau_{\text {лрел }}=I_{a} \frac{U_{\text {вне }}}{U_{a}}\left(U_{a}-U_{\text {вне }}\right) \tau_{\text {лрел }}=-\frac{q N}{\tau_{a}} U_{a} \frac{U_{\text {вне }}}{U_{a}}\left(1-\frac{U_{\text {вне }}}{U_{a}}\right) \tau_{\text {лрел }}=-q N U_{a} \frac{E_{\text {вне }}}{E_{a}}\left(1-\frac{E_{\text {вне }}}{E_{a}}\right) \frac{\tau_{\text {лрел }}}{\tau_{a}} \text {. }
$$

Having divided both parts of equality (8) into full number of electrons of conductivity in Gunn diode of particles of $N$, we will define the energy received by each electron from a source during the average time of a relaxation $\tau_{\text {лper }}$

$$
w_{N}=w_{\text {вне }}+w_{\text {nер }}+w_{\text {рдом }} .
$$

In equality (14) composed by $w_{\text {вне }}$ defines the kinetic energy of the chaotic movement of electrons out of the domain turning into thermal energy. It determines the size of an integral Lagrangian [4-7]

$$
\Lambda_{\text {min }}=m_{1}\left(v_{\text {лор }}^{2}\right)_{\min }=\left(w_{\text {вне }}\right)_{\min }=\left(w_{N}-w_{\text {пер }}-w_{\text {рдом }}\right)_{\min } .
$$

According to expressions (11) and (12) with growth strengths of electric field to $E_{a}$, attached of Gunn diode, $w_{\text {рдом }}$ grow and $w_{\text {вне }}$ decreases. In other words, with growth of tension at $E>E_{\text {крит }}$ in GaAs the electric domain will begin to be formed. Due to redistribution of number of «light» and «heavy» electrons the number of «heavy» electrons will increase and to decrease at the same time number of «light». It will be followed by reduction of average kinetic energy of «light» electrons. At establishment of steady state of the diode integral Lagragian (15) will accept the minimum value [8,9]. Thus, the main mechanisms of selforganization of electrons in Gunn diode under the influence of external electric field of $E>E_{\text {kpum }}$ are:

- emergence of the «heavy» electrons connected with features of a power range of GaAs;

- increase in number of «heavy» electrons due to reduction of number of «light»;

- growth of potential energy of «heavy» electrons due to reduction of kinetic energy of the chaotic movement of «light» electrons;

- reduction of the integral Lagrangian corresponding to electrons of Gunn diode to a minimum.

\section{References}

1 Шур М. Современные приборы на основе арсенида галлия. - М.: Мир, 1991. - 632 с.

2 Левинштейн М.Е., Пожела Ю.К., Шур М.С. Эффект Ганна. - М.: Сов. радио, 1975. — 288 с.

3 Шелль Э. Самоорганизация в полупроводниках. Неравновесные фазовые переходы, обусловленные генерационнорекомбинационными процессами: Пер. с англ. - М.: Мир, 1991.

4 Доменная электрическая неустойчивость в полупроводниках / В.Л. Бонч-Бруевич, И.П. Звягин, А.Г. Миронов. - М.: Гл. ред. физ.-мат. лит. изд-ва «Наука», 1972.

5 Пасынков В.В., Чиркин Л.К. Полупроводниковые приборы. - М.: Высш. шк., 1987.

6 Усыченко В.Г. Самоорганизация электронов в электронных приборах // Журнал технической физики. — 2004. — Т. 74. - Вып. 11. - С. 38-46.

7 Усыченко В.Г. Энтропия, информация и сложность стационарных состояний открытых систем, не удовлетворяющих принципу локального равновесия // Журнал технической физики. — 2005. — Т. 75. — Вып. 5. — С. $19-27$.

8 Усыченко В.Г. Самоорганизация электронов в электронных приборах в свете принципов механики и термодинамики // Журнал технической физики. - 2006. - Т. 76. - Вып. 4. - С. 17-27.

9 Усыченко В.Г. Электронная синергетика. Физические основы самоорганизации и эволюции материи: Курс лекций. - СПб.: Лань, 2010 с.: ил. — (Учебники для вузов. Спец. литература). 


\title{
Л.В. Чиркова, К.Т. Ермаганбетов, Э.В. Скубневский, К.М. Маханов, Е.Т. Аринова, А. Омирбек \\ Ганн диодындағы физикалық процестер және энергия балансы
}

\begin{abstract}
Шамасы шектік кернеуден артық сыртқы кернеудің әсерінен Ганн диодында жүретін физикалық үдерістер талданған. Арсенид галлий шалаөткізгішінің төменгі орталық энергия өлкесінен жоғары бүйірде орналасқан энергия өлкесіне көшу нәтижесінде электрондар қозғалғыштықтары әр түрлі үлкен және кішіге - бөлінетіндігі көрсетілген. Кедергісі шалаөткізгіштің басқа бөлігінің кедергісінен үлкен электр домені пайда болатындығы айтылған. Электр доменіндегі кернеудің төмендеуі оның сыртындағы өңірдегі кернеудің төмендеуінен артық болады. Сыртқы кернеу артқанда домендегі кернеудің төмендеуі өсіп, оның сыртындағы өңірде кернеу азаяды, нәтижесінде домендегі электрондардың ығу жылдамдығы артады, ал сыртқы өңірдегі электрондардың ығу жылдамдығы төмендейді. Доменнің ішіндегі электрондардың орташа ығу жылдамдығы сыртқы электрондардың орташа ығу жылдамдығымен теңескенде домен толығымен қалыптасады. Ганн диодында орныққан күй орнағанда интегралдық лагранжиан ең аз мән қабылдайтындығы көрсетілген.
\end{abstract}

Кілm сөздер: энергетикалық спектр, энергетикалық алқабы, электрон, дрейфті жылдамдық, лагранжиан, интеграл, әлеует, электр өрісінің кернеулігі, электр домен, Ганн диоды.

\author{
Л.В. Чиркова, К.Т. Ермаганбетов, Э.В. Скубневский, \\ К.М. Маханов, Е.Т. Аринова, А. Омирбек
}

\section{Физические процессы в диоде Ганна и баланс энергии}

\begin{abstract}
В статье рассмотрены физические процессы, происходящие в диоде Ганна, находящемся под действием внешнего электрического поля, превышающего пороговое значение. Показано, что из-за перехода электронов из нижней центральной энергетической зоны в верхнюю боковую долину энергетического спектра арсенида галлия носители заряда делятся на две группы: «легкие» и «тяжелые» электроны, обладающие большими и меньшими подвижностями. Образуется электрический домен, сопротивление которого превышает сопротивление остальной части диода Ганна. В результате напряженность внутреннего электрического поля диода будет превышать напряженность электрического поля вне домена. С ростом напряженности внешнего поля падение потенциала на области домена растет, а вне домена уменьшается. С ростом напряженности внешнего электрического поля дрейфовая скорость электронов домена растет, в то время как дрейфовая скорость электронов вне домена уменьшается. Когда дрейфовые скорости электронов в домене и вне его сравниваются, формирование домена завершается. Показано, что в диоде Ганна устанавливается стационарное состояние, когда интегральный лагранжиан принимает минимальное значение.
\end{abstract}

Ключевые слова: энергетический спектр, энергетические долины, электрон, дрейфовая скорость, лагранжиан, интеграл, потенциал, напряженность электрического поля, электрический домен, диод Ганна.

\section{References}

1 Schur M. Modern devices on the basis of gallium arsenide, Moscow: Mir, 1991, $632 \mathrm{p}$.

2 Levinshtein M.E., Pozhela Yu.K., Shur M.S. Gunn effect, Moscow: Sovetskoe radio, 1975, 288.

3 Shell E. Self-organization in semiconductors. The nonequilibrium phase transitions caused generatsionno-recombinational processes, the lane with English, Moscow: Mir, 1991.

4 Domain electric instability in semiconductors. V.L. Bonch-Bruyevich, I.P. Zvyagin, A.G. Mironov, Moscow: main edition of physical and mathematical literature of Nauka publishing house, 1972.

5 Pasynkov V.V., Chirkin L.K. Semiconductor devices, Moscow: Vysshaya shkola, 1987.

6 Usychenko V.G. Journal of Technical Physics, 2004, 74, 11, p. 38-46.

7 Usychenko V.G. Journal of Technical Physics, 2005, 75, 5, p. 19-27.

8 Usychenko V.G. Journal of Technical Physics, 2006, 76, 4, p. 17-27.

9 Usychenko V.G. Electronic synergetrics. Physical bases of self-organization and evolution of matter: Lecture course, Saint Petersburg: Lan, 2010 pages: silt. — (Textbooks for higher education institutions. Special literature). 